\title{
Experimental Investigation of Connection Details on the Cyclic Performance of All-steel Tubular Buckling Restrained Braces
}

\author{
Seayf Allah Hemati ${ }^{*}$, Ali Kheyroddin², Mohammad Ali Barkhordari Bafghi ${ }^{1}$ \\ 1 School of Civil Engineering, Iran University of Science and Technology, Tehran, P.O. Box 16846-13114, Iran \\ 2 School of Civil Engineering, Semnan University, Semnan, 19111-35131, Iran \\ * Corresponding author, e-mail: shemati@semnan.ac.ir
}

Received: 15 November 2019, Accepted: 18 May 2020, Published online: 10 June 2020

\begin{abstract}
To eliminate the geometrical defects and to reduce the damage caused by out-off-plane rotation of the end portion of the conventional buckling restrained braces, as well as introducing a new way to facilitate the construction and installation process, the experimental behavior of 5 proposed specimens as new type of all-steel tubular buckling restrained braces (AST-BRB) under cyclic axial loads was studied.

The proposed specimens consist of a steel tube as a load bearing member (core), which is placed inside a larger tube as a buckling restraining member (pod). At the two ends of the core member, different end details and connection (compared to the common BRBs) are provided as the elastic transitional region. The performance of the specimens were evaluated based on indices, such as damage mode, repeatable behavior, adjusted strength factors, load-bearing capacity, and cumulative inelastic displacement.

The evaluation of the results indicated that, the specimens, which welded variable cross-section steel lids at both ends of the core, have superior seismic performance. The superior specimens, for all cycles with larger displacements of the yielding displacement, exhibited a stable hysteresis behavior in bearing of cyclic loads. The bearing pressure was about 1.07 times greater than the tensile load. The cumulative inelastic axial displacements of these specimens is at least 209 times of their yield displacement. Meanwhile, they can tolerate at least $140 \%$ compressive load and $10 \%$ greater tension loads relative to the nominal capacity of the core individual.
\end{abstract}

\section{Keywords}

all-steel tubular buckling-restrained brace, hysteresis behavior, load-bearing capacity

\section{Introduction}

Ordinary braces perform well under tensile loads entering the inelastic range, but under pressure buckle and they do not have a satisfactorily performance within the inelastic range. To resolve this defect, Takaeda et al. [1] first came up with the idea of buckling-restrained braces (BRBs) in the 1970 s.

The introduced BRBs are made of a core steel plate as a bearing member, placed into a steel hollow structural section filled by concrete as a restraining unit (pod) [2-5].

Defects such as being bulky, lengthy construction time, difficulty in construction and installation, as well as heavyweight of the concrete, have limited the use of conventional BRBs to specific buildings; as such, engineers and designers are less likely to use them in public buildings.

Other developed BRBs, are all steel BRBs, in which the restrainer member is usually made of several steel pieces, such as plates, angles, channels, or their combination. These pieces are assembled by welding or through bolt and nuts and, they prevent the buckling of the core member by their own resistance. Some of the advantages of all-steel BRBs, compared to the conventional BRBs, are as follows: (i) the minimum executive problems of the installation process; (ii) the inexpensiveness due to their light weight, and also no special technology is necessary for their construction and installation [6-16].

The BRBs have a symmetrical behavior under compressive and tensile loading. The structural frames equipped with BRBs possess a high bearing capacity and they can show satisfactory performance in earthquake events. This desirable behavior has prompted researchers to numerically or experimentally examine various types of braces in various shapes and materials [17-28], or small and large scales [29-32], either directly or subassemblage [33-41]. 
In recent years, engineers and building designers have also shown interest in using the BRB for designing new buildings and retrofitting existing buildings [42-45]. In addition, valid building regulations and rules have allocated parts of the regulations to this issue [46-50]

The experimental research indicated that, (almost) in all BRBs, whether conventional or all-steel, a local damage occurs due to the out-off-plane rotation and plastic hinges at the two ends of the brace [51-55], as well as the low gyration radius of the core member relative to its weak axis.

There was an experimental project conducted to introduce a new type of all-steel brace, which first possesses the same seismic specifications as with BRB; and secondly, it will minimize the local damage at the two ends of the brace. Furthermore, the cost of construction and installation of the brace is reduced by removing or minimizing the cross-section of steel stiffener plates, welds, bolt, and nuts required for the assembly of pods and shortening the construction time.

Accordingly, 10 different prototype models (specimens) with different steel sections for the pod and various end connections were considered as BRBs. Briefly, the proposed BRBs consist of a steel tube as a core member, inserted into a larger tube, or two steel angles as pods. Also, at the two ends of the core member, different details (compared to the common BRBs) are provided as the elastic transitional region and end connection.

The paper about the investigation of pod on the seismic behavior of the 5 proposed specimens has already been published [56].

In this article, the effect of the 3 proposed models of the connection details on the seismic performance of 3 new small-scale specimens is reported. In addition to introducing the superior end connection details, the performance of the two other specimens (including a pod specimen and a specimen without pod as a control specimen), which are made with medium scale and conforming to the superior connection, is described.

\section{Experimental program}

\subsection{Specified material properties of the specimens}

Seamless tubes (Mannesmann) have been used as core members of specimens. As this type of tube is seamless, it is expected to perform better during an earthquake compared to other tubes. Nevertheless, this issue is recommended to be explored in future projects. Mechanical Properties and Stress Results - Crushing of the tube used in the core member of the first three specimens (made on a
Table 1 Mechanical properties of the main components of the test specimens

\begin{tabular}{lccccc}
\hline Section & $\begin{array}{c}F_{y} \\
(\mathrm{MPa})\end{array}$ & $\begin{array}{c}F_{u} \\
(\mathrm{MPa}\end{array}$ & $\begin{array}{c}\varepsilon_{y} \\
(\%)\end{array}$ & $\begin{array}{c}E \\
(\mathrm{GPa})\end{array}$ & $v$ \\
\hline Tube3/4 & 360 & 480 & 0.24 & 205 & 0.3 \\
Tube1, 1/4 \& 2 & 240 & 370 & 0.2 & 205 & 0.3 \\
\hline
\end{tabular}

small scale) was determined by direct tensile testing. Also, the mechanical features of the pod of each five specimen and core member of the two last specimens considered by the presented features of manufacturers have been shown in Table 1. This table includes the following parameters: $f_{y}$ yield stress, $f_{u}$ final stress; $E$ Young's modulus, $\varepsilon_{y}$ yield strain, and $\gamma$ Poisson's ratio of aggregate.

\subsection{Design, constructional arrangement, and fabrication of the test specimens}

The lengths of the core members are designed such that, firstly, they resist the maximum compressive load of the brace, while forming plastic hinges when the core member reaches the target strain [9], and secondly, the slimming coefficient of the core member is equal across all specimens, so that the results of the experiments can be compared to each other. Furthermore, the buckling of an individual all-steel BRB with single core member does not occur before the overall instability of the specimen under cyclic loads [42]. The length of the pod is shorter than the core, so that during the experiment, the axial displacement of the core member is not transmitted to the pod. It has been recommended that, for improving the cyclic performance of all-steel BRBs the gap between the core and the pod should be kept at the minimum; as such, a smaller gap would be beneficial to the design [8]. On the other hand, the very small gap between the core member and the pod may transfer the core member force to the pod and complicate the brace function and thus, causing design hardening [25]. Therefore, the distance between the pod and the core members should be selected as minimum as possible, while the core member during the test can move easily (without friction) into the pod, preventing force transfer or axial displacement of the core to the pod. According to items above, Table 2 presents the geometrical characteristics of the test specimens.

The 3 small-scale specimens are called PES-SBRB, NWS-BRB, and CP1-LBRB, the control specimen is NP-LBRB, and the last specimen is called CP2-LBRB.

Constructional arrangement of the test specimens can be summarized as follows: 
- Welding the adjoining parts at one end of the core.

- Inserting the core member inside the pod.

- Welding the adjoining parts at the other end of the core.

- Welding the prepared set to the end plates.
The assembly process of the NP-LBRB specimen is similar to the two CP1-LBRB and CP2-LBRB specimens, except that there is no pods around the core.

Table 3 indicates the specific manufacturing steps for each specimen.

Table 2 Key geometric parameters of the test specimens

\begin{tabular}{|c|c|c|c|c|c|c|c|c|c|}
\hline Specimen & Member & Section & $\begin{array}{l}\text { Length } \\
L(\mathrm{~mm})\end{array}$ & $\begin{array}{c}\text { Medium } \\
\text { diameter } D_{m} \\
(\mathrm{~mm})\end{array}$ & $\begin{array}{c}\text { Thickness } t \\
\text { (mm) }\end{array}$ & $\begin{array}{c}\text { Gap between } \\
\text { core to pod } \\
(\mathrm{mm})\end{array}$ & $\begin{array}{c}\text { Area } A \\
\left(\mathrm{~mm}^{2}\right)\end{array}$ & $\begin{array}{c}\text { Moment } \\
\text { of inertia } I \\
\left(\mathrm{~mm}^{4}\right)\end{array}$ & $\begin{array}{c}\text { Gyration } \\
\text { radius } r \\
(\mathrm{~mm})\end{array}$ \\
\hline \multirow{2}{*}{$\begin{array}{l}\text { PES-SBRB } \\
\text { NWS-BRB, } \\
\text { CP1-LBRB }\end{array}$} & Pod & Tube1,1/4 & 1050 & 39.03 & 3.59 & \multirow[b]{2}{*}{4} & 440 & 83778 & 13.80 \\
\hline & Core & Tube3/4 & 1150 & 24.25 & 2.87 & & 219 & 16064 & 8.57 \\
\hline \multirow{2}{*}{ NP-LBRB } & Pod & & \multicolumn{4}{|c|}{ NO } & \multicolumn{3}{|c|}{1150} \\
\hline & Core & Tube1,1/4 & 1750 & 39.03 & 3.59 & - & 440 & 83778 & 13.80 \\
\hline \multirow{2}{*}{ CP2-LBRB } & Pod & Tube 2 & 1650 & 56.39 & 3.91 & \multirow{2}{*}{5.1} & 693 & 275183 & 19.94 \\
\hline & Core & Tube1,1/4 & 1750 & 39.03 & 3.59 & & 440 & 83778 & 13.80 \\
\hline
\end{tabular}

Table 3 Constructional arrangement of the specimen

\begin{tabular}{llll}
\hline $\begin{array}{l}\text { Constructional } \\
\text { arrangement }\end{array}$ & 1 & 2 & 3 \\
Specimen & & & 4 \\
\hline
\end{tabular}

\begin{tabular}{|c|c|c|c|c|}
\hline \multirow[t]{2}{*}{ PES-SBRB } & $\begin{array}{c}\text { Longitudinal } \\
\text { Connection } \\
\text { stiffening plates } \\
\text { segments }\end{array}$ & Pod end slot & c & End plates \\
\hline & $\begin{array}{c}\text { Connection stiffener } \\
\text { segments and Longitudinal } \\
\text { stiffening plates welded to } \\
\text { one end of the core } a, b\end{array}$ & A core placed within pod & $\begin{array}{l}\text { Connection stiffener } \\
\text { segments and Longitudinal } \\
\text { stiffening plates welded to } \\
\text { other end of the core } a, b\end{array}$ & $\begin{array}{l}\text { Specimen welded to both } \\
\text { end plates a, c }\end{array}$ \\
\hline \multirow[t]{2}{*}{ NWS-BRB } & & & & \\
\hline & $\begin{array}{l}\text { Longitudinal stiffening } \\
\text { plates welded to one end } \\
\text { of the core } a, b\end{array}$ & A core placed within pod & $\begin{array}{l}\text { Longitudinal stiffening } \\
\text { plates welded to other end } \\
\text { of core } a, b\end{array}$ & $\begin{array}{c}\text { Specimen welded to both } \\
\text { end plates a, c }\end{array}$ \\
\hline \multirow[t]{2}{*}{$\begin{array}{l}\text { CP1-LBRB } \\
\& \\
\text { CP2-LBRB }\end{array}$} & Steel Lid & & & \\
\hline & $\begin{array}{l}\text { A lid welded to one end of } \\
\text { core } a, b\end{array}$ & A core placed within pod & $\begin{array}{l}\text { A lid welded to other end } \\
\text { of core } a, b\end{array}$ & $\begin{array}{l}\text { Specimen welded to both } \\
\text { end plates a, c }\end{array}$ \\
\hline
\end{tabular}

a) The E6010 electrode is used for welding, b) The effective thickness of the welds is $3 \mathrm{~mm}$, c) The effective thickness of the welds is $5 \mathrm{~mm}$ 

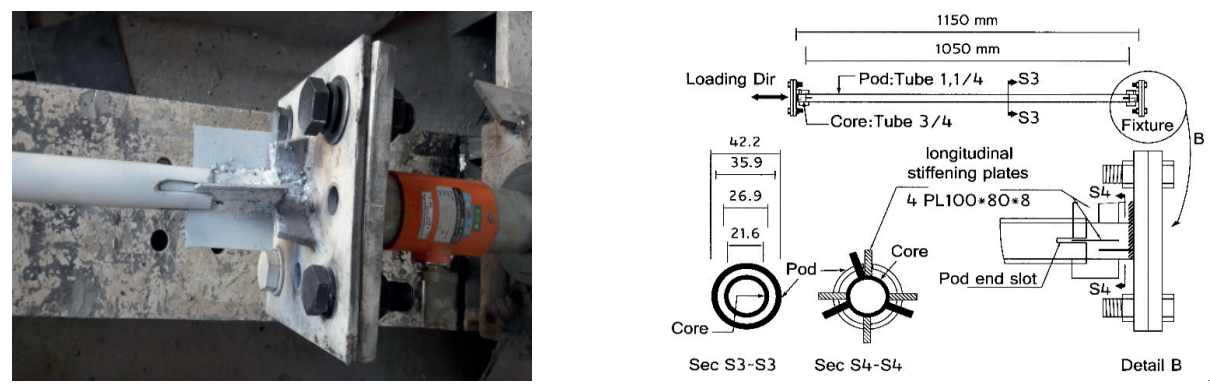

(a) PES-SBRB specimen
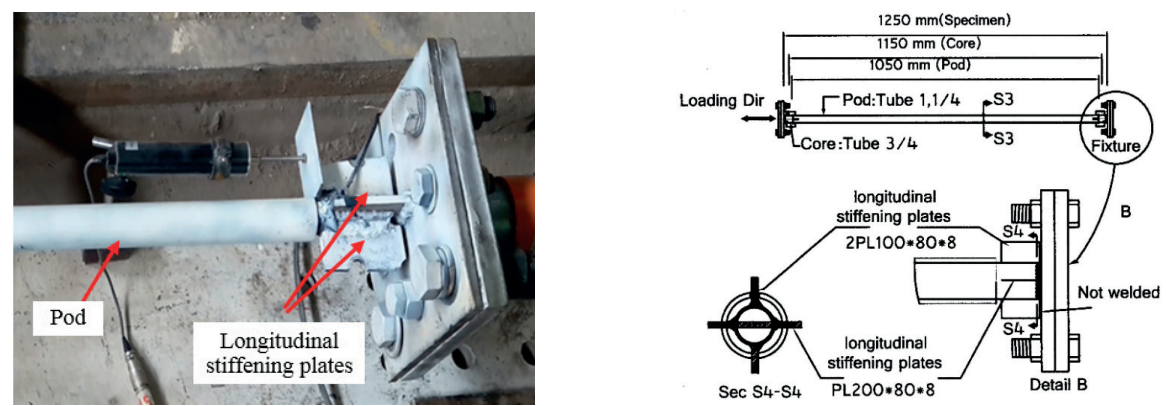

(b) NWS-BRB specimen
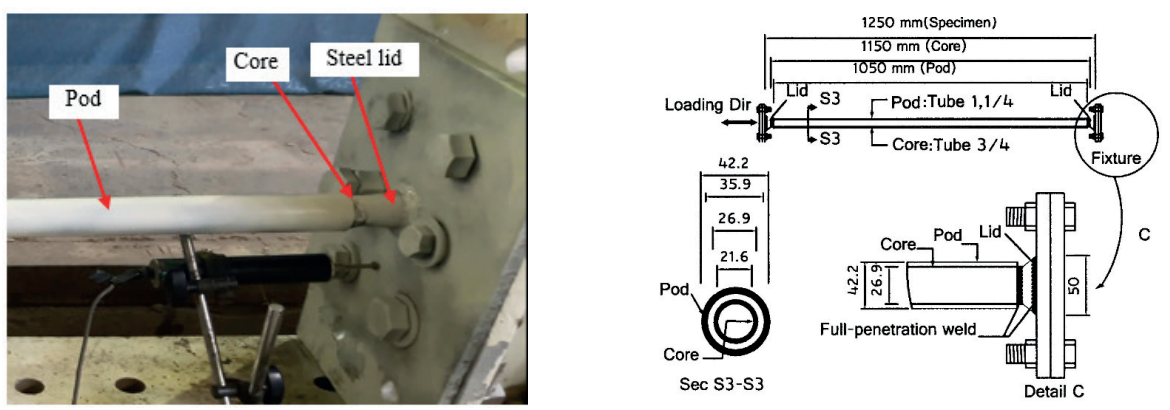

(c) CP1-LBRB specimen
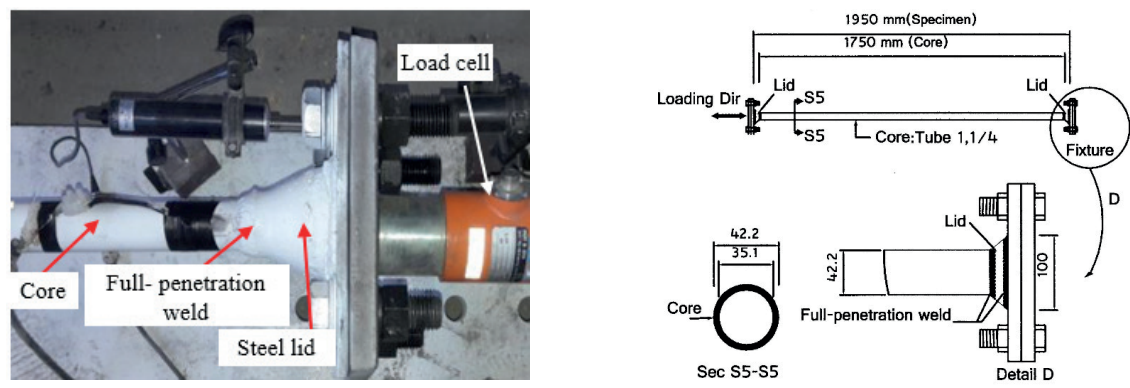

(d) NP-LBRB specimen
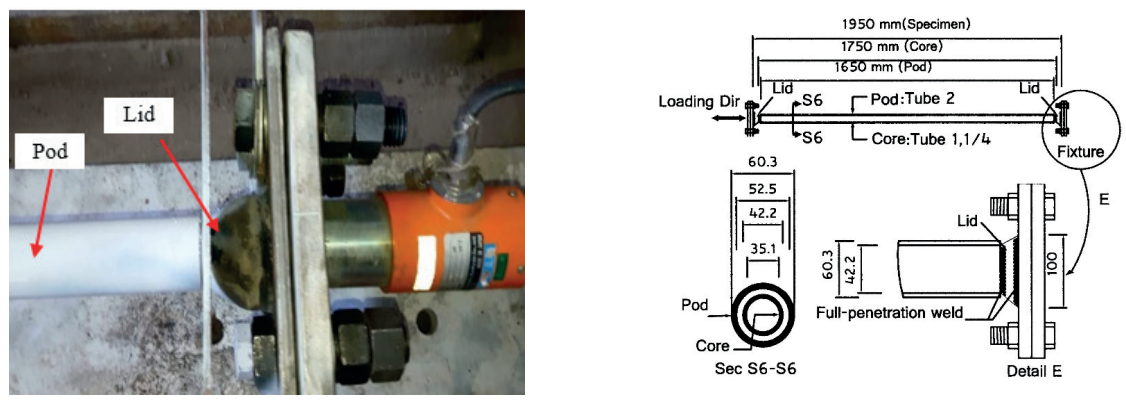

(e) CP2-LBRB specimen

Fig. 1 Photo and connection erection detailing of test specimen 
Figs. 1(a-e) present the shop drawings, geometric dimensions, fabrication details, and a photograph of the end connection of the specimens employed in this study.

The end region of core member of both PES-SBRB and NWS-BRB specimens, was reinforced by welding 4 the longitudinal stiffening plates to keep it elastic (Figs. 1(a) and 1(b)). In the two extreme edges of the pod of PESSBRB specimen, 4 slots have been created to allow longitudinal stiffening plates to move easily into the slots during the test, and also the compressive axial force is not transferred from the core member to the pod. In The PESSBRB specimen in addition to full penetration welding of core member, three support stiffening segment are used for connection (Fig. 1(a)).

But the NWS-BRB specimen was connected to the end plate only through full penetration welding of the core member (Fig. 1(b)).

In the NP-LBRB (control specimen), CP1-LBRB, and CP2-LBRB specimens, both end region of core member of the longitudinal stiffening plates and support stiffening segment are replaced by a steel lid, which has a cross-sectional variable and its diameter gradually extends from the ends of the core member to the end plate (Fig. 1(c-e)).

\subsection{Test setup}

The test setup includes the specimen, strong bases, measuring instruments, and a data logger device assembled through a suitable and reliable method prior to testing. One end of the specimen is connected to the strong base via the end plate, while the other end of the specimen is connected to the load cell device via the end plate. Axial loads were applied to the specimens through a $2000 \mathrm{kN}$ hydraulic jack and measured by a recurrent load cell. At each end of the specimen, pairs of linear variable displacement transducers (LVDT) were placed to measure the axial displacement of the core member. They way the test specimen and other test equipment have been installed is shown in Fig. 2.

\subsection{Loading protocol}

The specific AISC 341-10 provisions [47] (for BRBs) were used, in order to evaluate the qualification of the proposed connection details from the loading protocol. This regulation specifies a sequence of quasi-static cyclic loading protocol, in terms of the displacement quantities corresponding to the first significant yielding $\left(\Delta_{b y}\right)$ and the minimum brace displacement demand $\left(\Delta_{b m}\right)$. This loading protocol prescribes two cycles at tension and compression $\Delta_{b y}, 0.5 \Delta_{b m}, \Delta_{b m}, 1.5 \Delta_{b m}$, along with $2 \Delta_{b m}$ displacement levels as shown in Fig. 3. Since BRBs are treated as hysteretic dampers, AISC requires an additional complete cycle of loading at the displacement corresponding to $\Delta_{b}=1.5 \Delta_{b m}$; which is required for the brace test specimen to achieve a cumulative inelastic axial displacement of at least 200 times of the yield displacement. It is noteworthy that, given the geometry of the test specimens, the axial elongation in the core member nearly corresponds to the story drift. In other words, for example, a story drift of $\Delta^{b}{ }_{h}=2 \%$ would induce a strain of $\varepsilon_{C}=2 \%$ in the core member [8]. Furthermore, the minimum brace displacement demand, $\Delta_{b m}$, cannot be considered less than $1 \%$ of the story height. Table 4 presents the sequence of loads applied to the specimens, according to the length of the specimens.

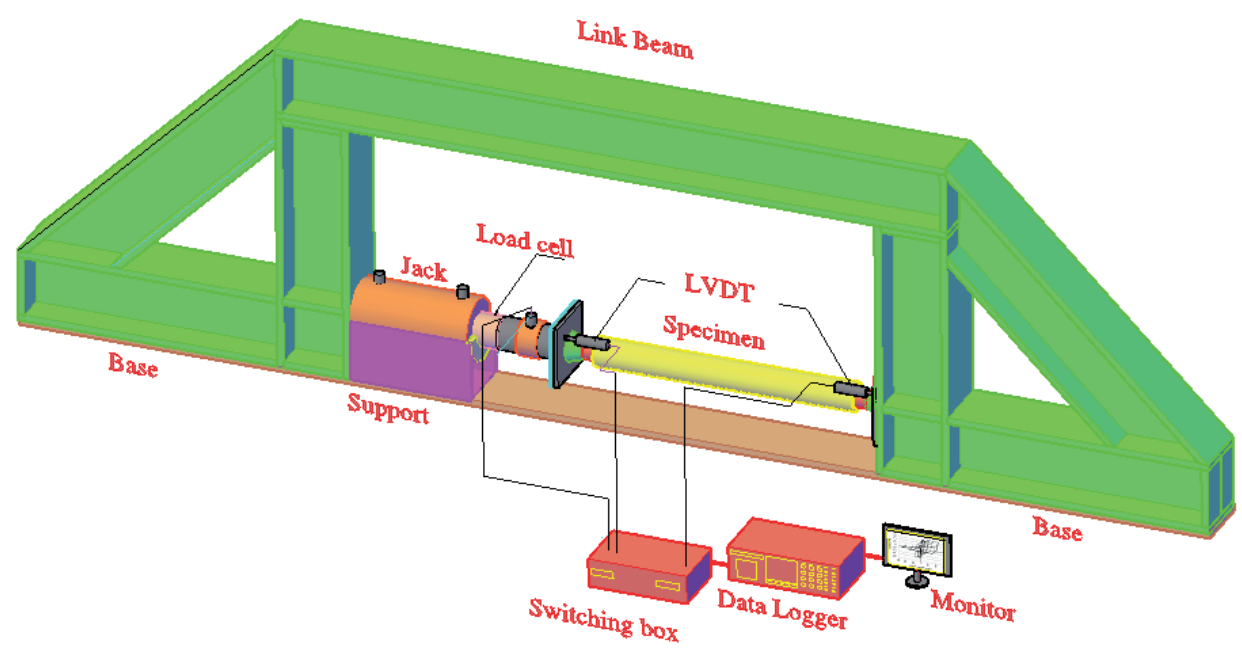

Fig. 2 Setup ready for the test 


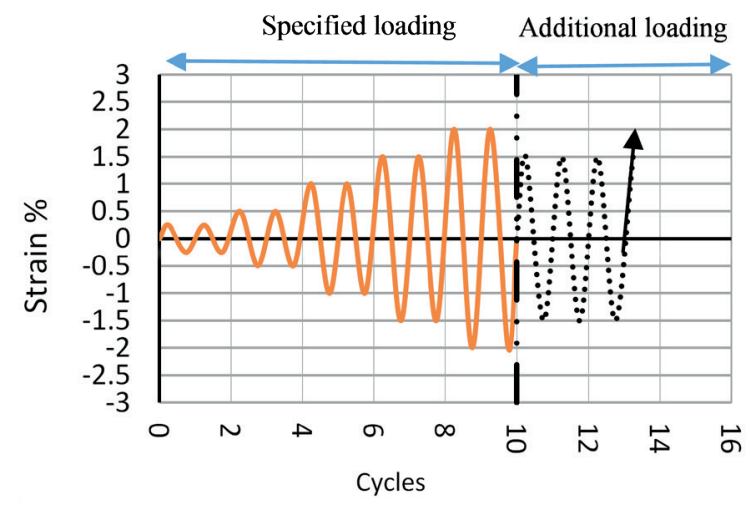

Fig. 3 Loading protocol of test specimens

\section{Test results of the specimens}

\subsection{Damage mode and rupture position}

Fig. 4 presents the damage mode and rupture position of the test specimens. The PES-SBRB specimen could only tolerate 9 complete cycles predicted by the loading protocol, accordingly, the first cycle is $\Delta_{b}=22.3 \mathrm{~mm}=2.0 \Delta_{b m}$. This specimen experienced three damage mode during the experiment, including (1) core member end longitudinal stiffeners bending damage, (2) core member end rotation, and (3) pod end edges local bending damage (Fig. 4(a)). The asymmetric performance of the specimen, in the tensile and pressure tolerance, started from the 7 th cycle $\left(\Delta_{b}=16.73 \mathrm{~mm}=1.5 \Delta_{b m}\right)$ with core member end longitudinal stiffeners bending damage. At the compression of $22.3 \mathrm{~mm}$ of the 9th loading cycle, the damage of the specimen was significantly increased and occurred at the core end rotation and pod end edges local bending, simultaneously. Eventually the core member rupture occurred in the tensile of the 10th cycle loading, in the vicinity of the connecting stiffeners (Fig. 4(b)).

The NWS-BRB specimen was rotated at the end of the core member, due to the removal of the support-stiffening segment and non-welding of the longitudinal stiffening plate edge to the end plates (Fig. 4(c)). This specimen could not tolerate more than 8 complete cycles predicted by the loading protocol, corresponding to $\Delta_{b}=16.73 \mathrm{~mm}=1.5 \Delta_{b m}$. The asymmetric performance of the specimen, started from the 5 th cycle $\left(\Delta_{b}=11.15 \mathrm{~mm}=\Delta_{b m}\right)$, and the compressive load of the specimen was significantly reduced in the 8th cycle of the compressive loading path, with a compression of $16.75 \mathrm{~mm}$. The 9th cycle and the compression path of $\Delta_{b}=22.3 \mathrm{~mm}=2.0 \Delta_{b m}$ experienced a general buckling after experiencing a $17.6 \mathrm{~mm}$ of compression displacement (Fig. 4(b)) and it could not tolerate greater loads. Accordingly, the experiment was continued only by applying a tensile load. Finally, following the partial hardening,
Table 4 Predicted loading sequence for the test specimens

\begin{tabular}{lccc}
\hline & & \multicolumn{2}{c}{ Axial displacement, $\Delta_{b},(\mathrm{~mm})$} \\
Sequence & Cycles & $\begin{array}{c}\text { PES-SBRB, } \\
\text { NWS-BRB, } \\
\text { CP1-LBRB }\end{array}$ & NP-LBRB \\
& & CP2-LBRB \\
\hline 1 & $2 @ \Delta_{b y}$ & \pm 2.76 & \pm 3.5 \\
2 & $2 @ 0.5 \Delta_{b m}$ & \pm 5.75 & \pm 8.75 \\
3 & $2 @ \Delta_{b m}$ & \pm 11.15 & \pm 17.50 \\
4 & $2 @ 1.5 \Delta_{b m}$ & \pm 16.73 & \pm 26.25 \\
5 & $2 @ 2 \Delta_{b m}$ & \pm 22.3 & \pm 35 \\
$6 *$ & $2 @ 2.5 \Delta_{b m}$ & \pm 27.87 & \pm 43.75 \\
7 & $\mathrm{n} @ 1.5 \Delta_{b m}$ & \pm 16.73 & \pm 26.25 \\
\hline
\end{tabular}

* After loading $2 \Delta_{b m}$, the specimen loading continues with $1.5 \Delta_{b m}$ until the cumulative inelastic displacement of $200 \Delta_{b y}$ is achieved

at the displacement of $\Delta_{b}=53.3 \mathrm{~mm}=4.8 \Delta_{b m}$, the core member was broken from the point where the specimen was attached to the strong base of the set up (Fig. 4(d)).

The CP1-LBRB and CP2-LBRB specimens showed more reasonable deformation compared to the other specimens, and the end lids were significantly effective in preventing the core end rotation. Sue to this reduction in the core end rotation, these specimens exhibited symmetrical behavior against compression and tensile loading during the test.

Furthermore, the CP1-LBRB specimen completed two additional cycles $\Delta_{b}=1.5 \Delta_{b m}$ before failure, and the CP2LBRB specimen also passed an additional full $\Delta_{b}=1.5 \Delta_{b m}$ before the experiment was completed. The tensile failure of the CP1-LBRB specimen (Fig. 4(f)) occurred at the end portion of the core member (near the end lid of the load cell). However, the CP2-LBRB specimen test (which loaded only $150 \mathrm{~mm}$ as a tensile displacement after the first additional loading cycle) was ended without breaking the core member, due to the lack of tongue Jacks. There was no rupture in lid welds. Also, there were no core instability or core member-to-end plate connection rupture in these types of the proposed specimens. Fig. 5 display the appearance of this specimen and residual elongation in the core member at end of the experiment and its separation from the setup.

As expected, the seismic performance of the NP-LBRB specimen was far weaker than the pod specimen. This specimen was only able to complete 5 full loading cycles, with a maximum compression of $\Delta_{b m}=17.5 \mathrm{~mm}=\Delta_{b}$, while the specimen performance along this path was also associated with a decline in compressive load capacity and overall buckling (Fig. 6(a)). The experiment was completed by abruptly cutting the specimen from the two-thirds of the 


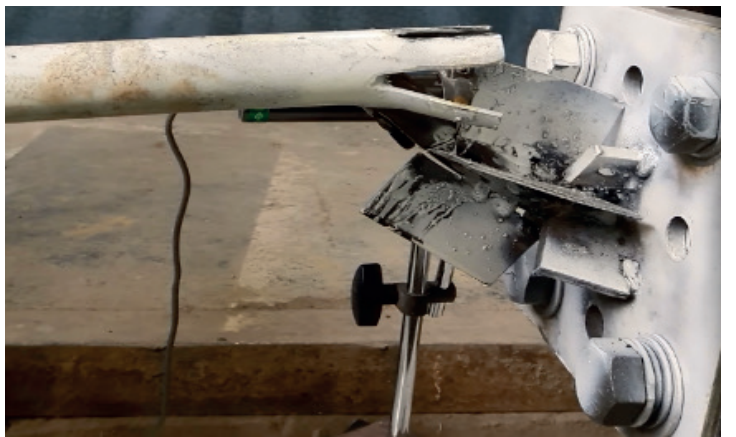

(a) Core end rotation and bending of the pod slotted edges of PES-SBRB at the compression of last loading cycle of the $\Delta_{b}=16.73 \mathrm{~mm}=1.5 \Delta_{b m}$

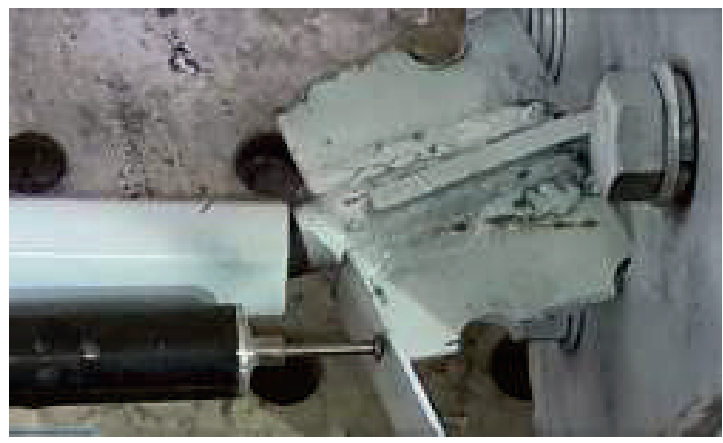

(c) End rotation of the core member of NWS-BRB at the compression of last loading cycle of the $\Delta_{b}=16.73 \mathrm{~mm}=1.5 \Delta_{b m}$

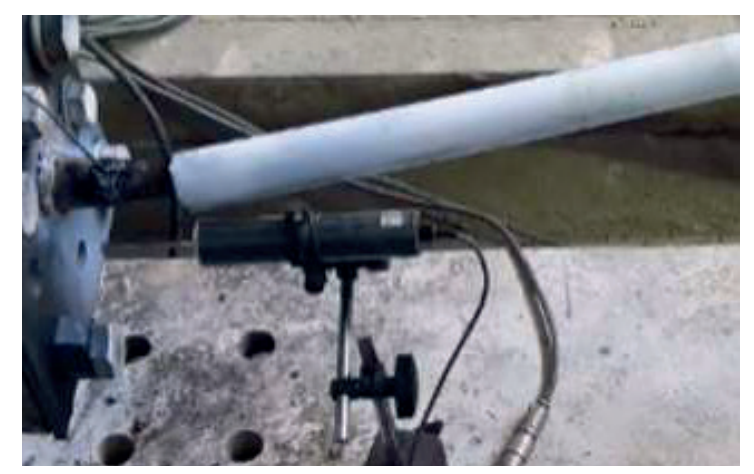

(e) End rotation of CP1-LBRB at the last compression loading cycle of $\Delta_{b}=16.73 \mathrm{~mm}=1.5 \Delta_{b m}$

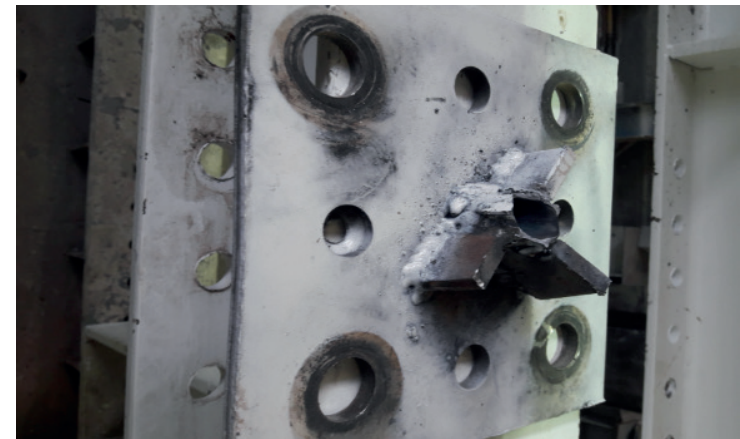

(b) Core rupture position of PES-SBRB at the tensile loading of the $\Delta_{h}=53.3 \mathrm{~mm}=4.8 \Delta_{b m}$

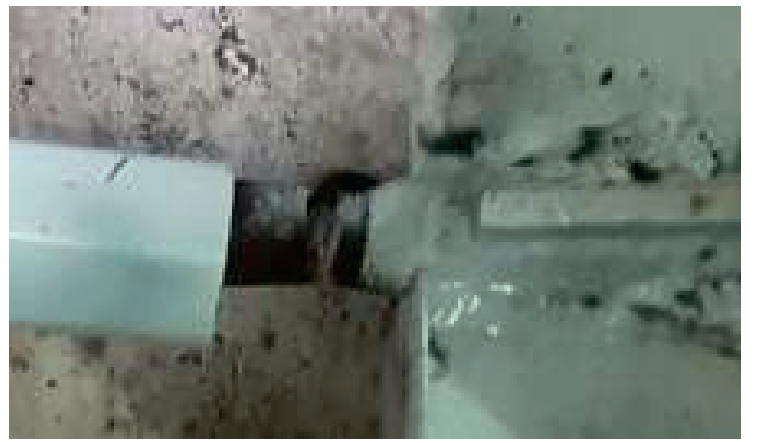

(d) Core rupture position of NWS-BRB at the tensile loading of the $\Delta_{b}=53.3 \mathrm{~mm}=4.8 \Delta_{b}$

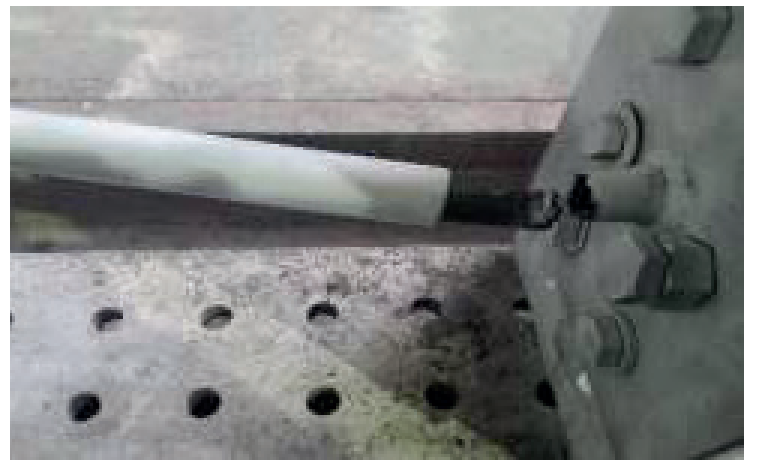

(f) Core rupture position of CP1-LBRB (In the tensile loading of the third additional cycle)

Fig. 4 Damage mode and core rupture position of the test specimens.

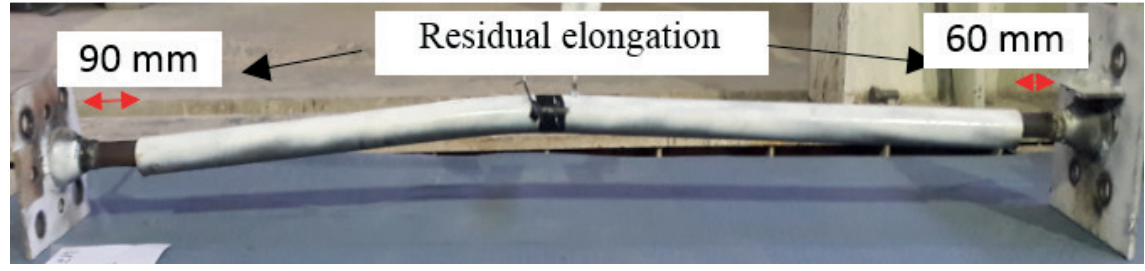

Fig. 5 Damage mode and core rupture position of the NP-LBRB specimen 


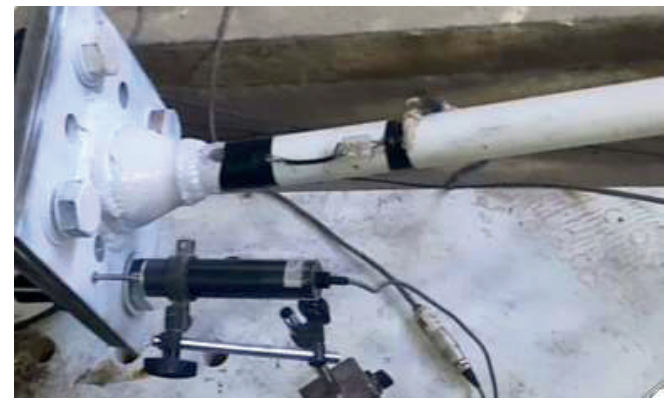

(a) End rotation of NP-LBRB at the last compression loading of the $\Delta_{b}=16.73 \mathrm{~mm}=1.5 \Delta_{b m}$

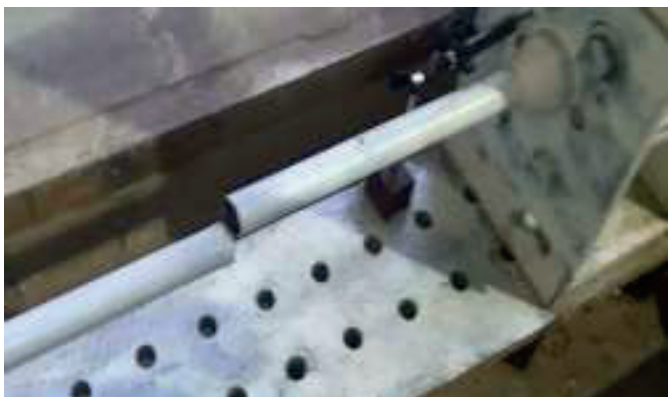

(b) rupture position of NP-LBRB at tensile of the $19.76 \mathrm{~mm}<1.5 \Delta_{b m} \Delta_{b}$

Fig. 6 Damage mode and core rupture position of the test specimens

end of the specimen (which has been used due to the weak molecular structure of the tube). Fig. 6(b) shows the specimen rupture position.

\subsection{Validation of the cyclic behavior of the test specimens}

Generally, the cyclic behavior of the test specimens, as BRBs, is evaluated through load-displacement hysteresis curves and based on indicators, such as the compressive strength adjustment factor $\beta$, the cumulative energy dissipation index, and bearing capacity of the specimens, which is governed by AISC 341-10 Building Code.

Figs. 7(a-e) illustrate the load-displacement responses and backbone curves of the specimens. The peak points of each hysteretic loop were related to the formation of the backbone curve. The vertical coordinate is the load applied to the specimen with the sign convention, which is positive for tension and negative for compression. The horizontal coordinate is the measured displacement value with the same sign convention.

As seen in Fig. 7, the CP1-LBRB and CP2-LBRB specimens, made by placing two steel tubes with different diameters inside each other and welding steel lids at the two ends of the inner tube, are compared to the NP-LBRB (control specimen) and other tested specimens, with the plump hysteresis curves exhibiting stable hysteretic and repeatable behavior without degradation of strength and stiffness. Therefore, the stiffness values of these specimens are increased after the yielding, due to the strain hardening effect.

\subsubsection{Adjusted test specimen strength factors}

The asymmetry of hysteresis curves might be because the cross-section of the core member tended to increase under compression due to the Poisson effect. Conversely, it tended to decrease under tension, leading to an asymmetrical behavior. The symmetric performance of the test specimens is generally evaluated by the compressive strength adjustment factor, $\beta$ which is obtained from a qualification test results of backbone curve, and it is defined by:

$\beta=\frac{C_{\max }}{T_{\max }}$

In which Cmax and Tmax represent the maximum compressive and tensile loads tolerated by the specimen, respectively, corresponding to $2.0 \Delta_{b y}$, and $\Delta_{b y}$ is the axial displacement, according to first significant yielding of the test specimen.

The $\beta$ factor depends on the details of the end connections, components dimensions of the specimen, material yield strength, and other detail features, determined by the experimental test [20]. However, AISC 341-10 recommends that the value of $\beta$ should lie between 1.0 and 1.3 to prevent asymmetry of loads. Generally, the $\beta$ factor variations for the all-steel buckling-restrained braces range from 1.05-1.15 [49]. The calculated $\beta$ values for the test specimens are given in Table 5.

The data available in Table 5 show that, the $\beta$ coefficient for the PES-SBRB, CP1-LBRB, and CP2-LBRB specimens is between 1 and 1.3. Therefore, symmetric performance index of the seismic acceptance criteria of AISC regulations for BRB is satisfied by these specimens. However, the values of $\beta$ for NWS-BRB and NP-LBRB specimens have been less than 1 . Therefore, they cannot satisfy the seismic requirements of the regulation for BRB.

\subsubsection{Increase in load-bearing capacity}

Based on the AISC requirements (for BRB), in each cycle with displacement greater than $\Delta_{b y}$, the maximum tension and compression loads values tolerated by the test specimen shall not be less than the nominal strength of the core member. Thus, the load-bearing capacity can be considered as a key criterion for validating the use of the 


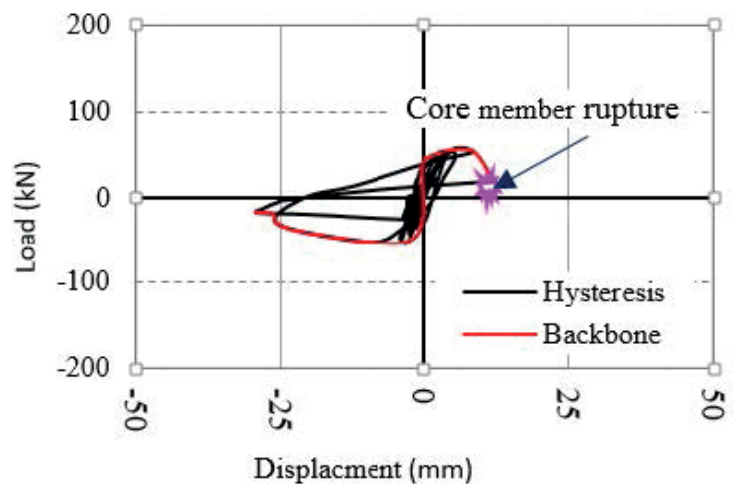

(a) PES-SBRB

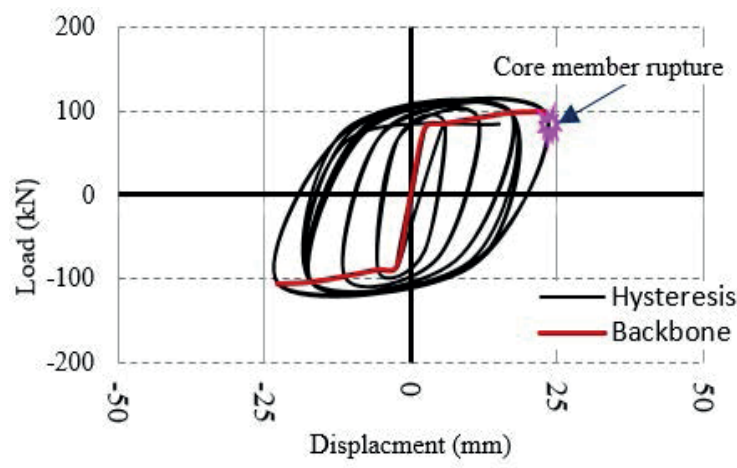

(c) CP1-LBRB

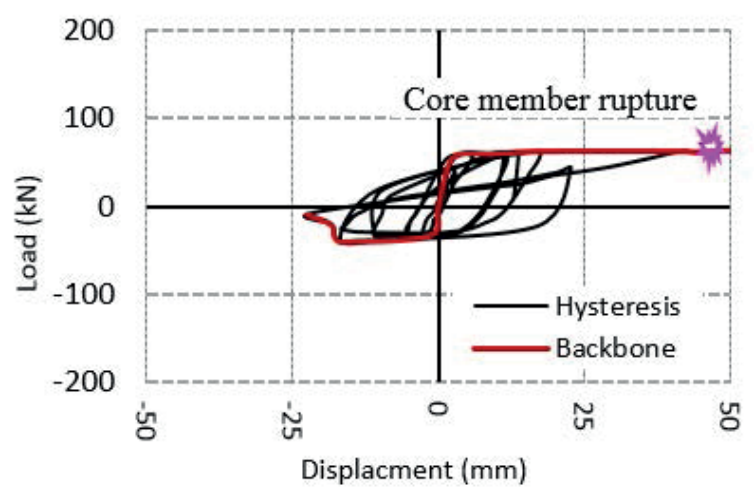

(b) NWS-BRB

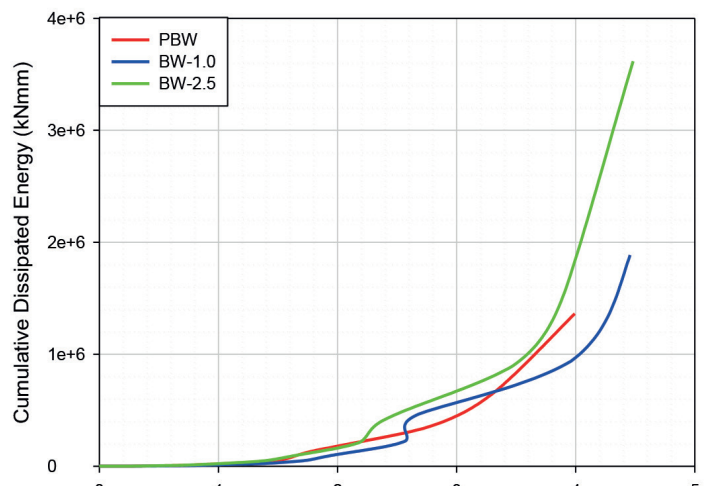

(d) NP-LBRB

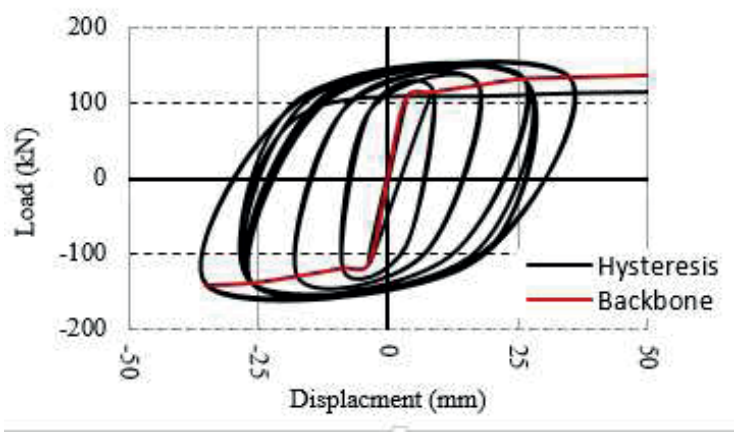

(e) CP2-LBRB

Fig. 7 Hysteretic and backbone curves of test specimens

Table 5 Determination of seismic performance indicators of the test specimens

\begin{tabular}{|c|c|c|c|c|c|}
\hline Specimen & PES-SBRB & NWS-BRB & CP1-LBRB & NP-LBRB & CP2-LBRB \\
\hline$C_{\max }(\mathrm{kN})$ & 53 & 40.1 & 106.8 & 45.29 & 143.44 \\
\hline$T_{\max }(\mathrm{kN})$ & 52 & 61.9 & 100.1 & 100.35 & 132.62 \\
\hline$\beta$ & 1.02 & 0.65 & 1.07 & 0.45 & 1.08 \\
\hline$P_{n}^{c}(\mathrm{kN})$ & 21.39 & 21.39 & 21.39 & 46.04 & 46.04 \\
\hline$P_{n}^{t}(\mathrm{kN})$ & 70.96 & 70.96 & 70.96 & 95.04 & 95.04 \\
\hline$P_{e y}^{c}(\mathrm{kN})$ & 46,7 & 33.3 & 84.4 & 45.25 & 112.27 \\
\hline$T_{y s c}=P_{e y}^{t}(\mathrm{kN})$ & 45,5 & 60.4 & 79.4 & 99.76 & 105.03 \\
\hline$\eta^{c}$ & 118.33 & 55.68 & 294.58 & -1.72 & 143.85 \\
\hline$\eta^{t}$ & -35.87 & -14.88 & 11.89 & 4.97 & 10.51 \\
\hline
\end{tabular}


proposed specimen as a BRB. Accordingly, a normalized expression bearing strength increase index can be defined for the tension and compressive by Eq. (2):

$\eta=\frac{P_{e y}-P_{n}}{P_{n}} * 100$.

The values of the loads tolerated by the test specimen, for tension and compression $P_{e y}^{t}$ and $P_{e y}^{c}$ are obtained from Fig. 6. Table 7 also presents the nominal compressive strength, $P_{n}$, for the core members, calculated according to AISC 360-16 [48].

As it can be seen in Table 5, except for the PES-SBRB and NWS-BRB specimens, whose maximum tolerated tensile load is below their nominal tensile capacity, and the compressive and tensile loads (especially the compressive load) tolerated by the CP1-LBRB and CP2-LBRB specimens have been far above their nominal core capacity. This means that the PES-SBRB and NWS-BRB specimens cannot satisfy this part of the AISC seismic regulation requirements for BRBs.

\subsubsection{Cumulative inelastic axial displacement (CID)}

Cumulative inelastic axial displacement (CID) can reflect the capability of a specimen to absorb seismic energy; therefore, it can be used to evaluate the seismic performance of the test specimens. The normalized inelastic axial displacement for each complete loading cycle (after $\Delta_{b y}$ ) is calculated by Eq. (3).

$\mu_{i}=\frac{4\left(\Delta_{b i}-\Delta_{b y, a v e}\right)}{\Delta_{b y, a v e}}$

The displacement corresponding to the yielding load is not equal to the tensile and pressure loading cycles. Therefore, in the above equation, the average absolute value of the axial displacement of the specimens in the tensile and compressive load of each cycle is assumed to be $\Delta_{b y, a v e}$. The normalized cumulative inelastic axial displacement, CID, was calculated through Eq. (4) as the summation of inelastic displacements for all completed cycles until the end of the experiment or specimen rupture (where $N$ includes preand post-displacement cycles of $2 \%$ specimen length).

$$
C I D=\sum_{i}^{N} \mu_{i}
$$

To satisfy the requirements for cyclic uniaxial testing of individual braces, AISC 341-10 [47] requires a BRB to achieve a cumulative inelastic axial displacement of 200

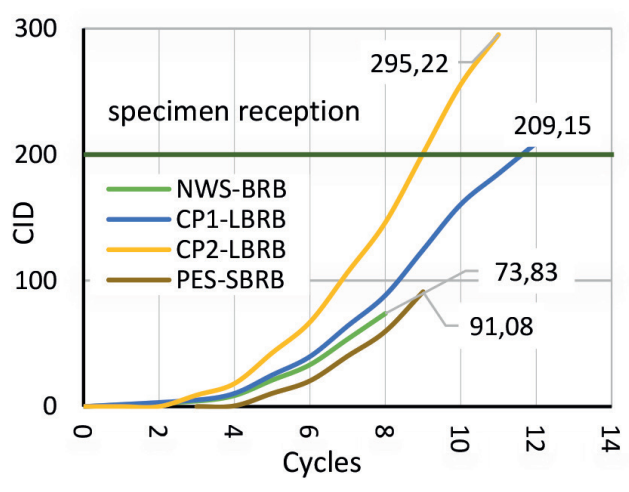

Fig. 8 Comparison of cumulative axial inelastic displacement of the specimens

times the yielding displacement. In Fig. 8, the cumulative inelastic axial displacement (CID) of the test specimens are compared.

As it can be seen in Fig. 7, the CP1-LBRB and CP2LBRB specimens were able to withstand more than 200 times of the yielding displacement by passing the loading cycles to the inelastic form before the end of the experiment. Therefore, the minimum energy dissipation condition of the AISC regulations is also met by these two specimens, so they can be considered as all-steel tubular buckling restrained braces (AST-BRB).

It should be noted that, the NP-BRB specimen did not virtually show any inelastic displacement because of its early buckling due to pressure and sudden tensile failure.

\section{Conclusions}

To eliminate the geometrical defects and to reduce the damage caused by out-off-plane rotation of the end portion of the conventional buckling restrained braces, as well as introducing a new way to facilitate the construction and installation process, the experimental behavior of five proposed specimens as new type of all-steel tubular buckling restrained braces (AST-BRB) under cyclic axial loads was studied.

By comparing the performance of the tested specimens, they were evaluated based on indices, such as damage mode, repeatable behavior, adjusted strength factors, loadbearing capacity, and cumulative inelastic displacement. Based on the performance of the specimens and the evaluation results, the following points can be extracted from this experimental study.

- The end details and the connection conditions can dramatically affect the cyclic performance of the proposed models as All-Steel Tubular BucklingRestrained Braces (AST-BRBs). 
- The CP1-LBRB and CP2-LBRB specimens, made by placing two steel tubes with different diameters inside each other and welding variable cross-section steel lids at the two ends of the inner tube (as the elastic transition zone), exhibit superior seismic performances and minimizing of the local damage at the two ends of the brace

- The superior specimens, exhibited a stable hysteresis behavior in bearing cyclic loads for all cycles with displacements larger than the yielding displacement. In these specimens, the bearing compressive was about 1.07 times greater than the bearing tensile. In addition, the cumulative inelastic axial displacements of the CP1-LBRB and CP2-LBRB specimens were more than 209 and 295 times of their yield displacement, respectively. Meanwhile, these two specimens, provided sufficiently rigid pods, which can tolerate at least $140 \%$ of the compressive load

\section{References}

[1] Takaeda, Y., Kimura, Y., Yoshioka, K., Furuya, N., Takemoto, Y. "An experimental study on braces encased in steel tube and mortal", In: Annual Meeting of the Architectural Institute of Japan, Tokyo, Japan, 1976, pp. 1041-1042. (in Japanese)

[2] Black, C. J., Makris, N., Aiken, I. D. "Component Testing, Seismic Evaluation and Characterization of Buckling-Restrained Braces", Journal of Structural Engineering, 130(6), 2004. https://doi.org/10.1061/(ASCE)0733-9445(2004)130:6(880)

[3] Watanabe, A., Hitomi, Y., Saeki, E., Wada, A., Fujimoto, M. "Properties of brace encased in buckling-retraining concrete and steel tube", Proceedings of Ninth World Conference on Earthquake Engineering, Tokyo-Kyoto, Japan, 1989, pp. 719-724. [online] Available at: https://www.iitk.ac.in/nicee/wcee/article/9_vol4_719.pdf

[4] Rahnavard, R., Naghavi, M., Aboudi, M., Suleiman, M. "Investigating modeling approaches of buckling-restrained braces under cyclic loads", Case Studies in Construction Materials, 8, pp. 476-488, 2018.

https://doi.org/10.1016/j.cscm.2018.04.002

[5] Jia, L.-J., Dong, Y., Ge, H., Kondo, K., Xiang, P. "Experimental Study on High-Performance Buckling-Restrained Braces with Perforated Core Plates", International Journal of Structural Stability and Dynamics, 19(1), Article number: 1940004, 2019.

https://doi.org/10.1142/S0219455419400042

[6] Ma, N., Wu, B., Li, H., Ou, J., Yang, W. "Full scale tests of all-steel buckling restrained braces", presented at: SPIE Smart Structures and Materials + Nondestructive Evaluation and Health Monitoring, San Diego, CA, USA, April, 6, 2009.

https://doi.org/10.1117/12.815665

[7] Chen, Q., Wang, C.-L., Meng, S., Zeng, B. "Effect of the unbonding materials on the mechanic behavior of all-steel buckling-restrained braces", Engineering Structures, 111, pp. 478-493, 2016. https://doi.org/10.1016/j.engstruct.2015.12.030 and the tension loads $10 \%$ greater than the nominal capacity of the core individual.

- When there are slots at the end edges of the pod, the core member end (of the PES-SBRB specimen) will easily undergo the pod end local bending damage. This damage mode can be avoided by implementing reasonable construction measures.

- In summary, based on the results of the study, this brace can be suggested to designers, civil engineers, and mechanical engineers, as an all-steel tubular buckling-restrained brace in structures, such as telecommunication towers, cranes, and trusses, which are often made with short piece assemblies.

- Nevertheless, the development and application of braces similar to the CP1-LBRB and CP2-LBRB specimens in the building require further studies (to include the plans of this research group).

[8] Dehghani, M., Tremblay, R. "Design and full-scale experimental evaluation of a seismically endurant steel buckling-restrained brace system", Earthquake Engineering \& Structural Dynamics, 47(1), pp. 105-129, 2017.

https://doi.org/10.1002/eqe.2941

[9] Ghowsi, A. F., Sahoo, D. R. "Experimental Study of All-Steel Buckling-Restrained Braces Under Cyclic Loading", In: Proceedings of the International Conference on Earthquake Engineering and Structural Dynamics, Reykjavik, Iceland, 2017, pp. 67-80. https://doi.org/10.1007/978-3-319-78187-7_6

[10] Guo, Y.-L., Tong, J.-Z., Wang, X.-A., Zhou, P. "Subassemblage tests and design of steel channels assembled buckling-restrained braces", Bulletin of Earthquake Engineering, 16, pp. 4191-4224, 2018. https://doi.org/10.1007/s10518-018-0337-5

[11] Razzaghi, S. A. S., Hatami, H. R. "Evaluating the Performance of the Buckling Restrained Braces in Tall Buildings with Peripherally Braced Frames", Journal of Rehabilitation in Civil Engineering, 7(2), pp. 21-39, 2019. https://doi.org/10.22075/JRCE.2018.12407.1213

[12] Bazzaz, M., Kafi, M. A., Kheyroddin, A., Andalib, Z., Esmaeili, H. "Evaluating the seismic performance of off-centre bracing system with circular element in optimum place", International Journal of Steel Structures, 14, pp. 293-304, 2014. https://doi.org/10.1007/s13296-014-2009-x

[13] Mohammadi, M., Kafi, M. A., Kheyroddin, A., Ronagh, H. R. "Experimental evaluation of an innovative buckling-restrained fuse for concentrically braced frames under cyclic loading", Article number: 333670528, 2019. (in Persian) https://doi.org/10.22065/JSCE.2019.182841.1838

[14] Fanaie, N., Dizaj, E. A. "Response modification factor of the frames braced with reduced yielding segment BRB", Structural Engineering and Mechanics, 50(1), pp. 1-17, 2014. https://doi.org/10.12989/sem.2014.50.1.001 
[15] Wang, K., Xia, J., Chen, X., Xu, B., Liang, X., Wang, J. "Performance of the cCold-Bending Channel-Angle Buckling-Restrained Brace under Cyclic Loading", Hindawi, Advances in Civil Engineering, Article ID: 9710529, 2019. https://doi.org/10.1155/2019/9710529

[16] Rahai, A. R., Mortazavi, M. "Experimental and Numerical Study on the Effect of Core Shape and Concrete Cover Length on the Behavior of BRBs", International Journal of Civil Engineering, 12(4), pp. 379-395, 2014. [online] Available at: http://ijce.iust.ac.ir/ article-1-876-en.html

[17] Jia, M., Yu, X., Lu, D., Lu, B. "Experimental research of assembled buckling-restrained braces wrapped with carbon or basalt fiber", Journal of Constructional Steel Research, 131, pp. 144-161, 2017. https://doi.org/10.1016/j.jcsr.2017.01.004

[18] Jia, L.-J., Ge, H., Maruyama, R., Shinohara, K. "Development of a novel high-performance all-steel fish-bone shaped", Engineering Structures 138, pp. 105-119, 2017. https://doi.org/10.1016/j.engstruct.2017.02.006

[19] Lin, P.-C., Takeuchi, T. "Seismic performance of buckling-restrained brace outrigger system in various configurations", Japan Architectural Review, 2(4), pp. 392-408, 2019. https://doi.org/10.1002/2475-8876.12120

[20] Li, W., Wu, B., Ding, Y., Zhao, J. "Experimental performance of buckling-restrained braces with steel cores of $\mathrm{H}$-section and half-wavelength evaluation of higher-order local buckling", Advances in Structural Engineering, 20(4), pp. 641-657, 2016. https://doi.org/10.1177/1369433216659491

[21] Wang, C.-L., Usami, T., Funayama, J., Imase, F. "Low-cycle fatigue testing of extruded aluminum alloy buckling-restrained braces", Engineering Structures, 46, pp. 294-301, 2013. https://doi.org/10.1016/j.engstruct.2012.07.016

[22] Jia, M., Guo, L., Lu, D. "Performance testing and comparison of buckling-restrained braces with $\mathrm{H}$ and crisscross cross section unrestrained segments", International Journal of Steel Structures, 14, pp. 745-753, 2014. https://doi.org/10.1007/s13296-014-1206-y

[23] Arbabi, F., Tabarok, M. "An experimental study on one of the all Steel Buckling Restrained Brace (S-BRB)", Amirkabir Journal of Science \& Research, 46(2), pp. 53-55, 2014.

[24] Park, J., Lee, J., Kim, J. "Cyclic test of buckling restrained braces composed of square steel rods and steel tube", Steel and Composite Structures, 13(5), pp. 423-436, 2012. https://doi.org/10.12989/scs.2012.13.5.423

[25] Guo, Y.-L., Zhang, B.-H., Zhu, B.-L., Zhou, P., Zhang, Y.-H., Tong, J.-Z. "Theoretical and experimental studies of battened bucklingrestrained braces", Engineering Structures, 136, pp. 312-328, 2017. https://doi.org/10.1016/j.engstruct.2017.01.034

[26] Mateus, J. A. S., Tagawa, H., Chen, X. "Buckling-restrained brace using round steel bar cores restrained by inner round steel tubes and outer square steel tube", Engineering Structures, 197, Article number: 109379,2019 https://doi.org/10.1016/j.engstruct.2019.109379

[27] Heidary-Torkamani, H., Maalek, S. "Conceptual numerical investigation of all-steel Tube-in-Tube buckling restrained braces", Journal of Constructional Steel Research, 139, pp. 220-235, 2017. https://doi.org/10.1016/j.jcsr.2017.09.022
[28] Shen, J., Seker, O., Sutchiewcharn, N., Akbas, B. "Cyclic behavior of buckling-controlled braces", Journal of Constructional Steel Research, 121, pp. 110-125, 2016. https://doi.org/10.1016/j.jcsr.2016.01.018

[29] Sugihardjo, H., Tavio, "Cumulative Ductility and Hysteretic Behavior of Small Buckling-Restrained Braces, Advances in Civil Engineering", 2017, Article ID: 7105768, 2017. https://doi.org/10.1155/2017/7105768

[30] Pandikkadavath, M. S., Sahoo, D. R. "Analytical investigation on cyclic response of buckling-restrained braces with short yielding core segments", International Journal of Steel Structures, 1, pp. 1273-1285, 2016. https://doi.org/10.1007/s13296-016-0083-y

[31] Hoveidae, N., Tremblay, R., Rafezy, B., Davaran, A. "Numerical investigation of seismic behavior of short-core all-steel buckling restrained braces", Journal of Constructional Steel Research, 114, pp. 89-99, 2015.

https://doi.org/10.1016/j.jcsr.2015.06.005

[32] Tabatabaei, S. A. R., Mirghaderi, S. R., Hosseini, A. "Experimental, and numerical developing of reduced length buckling-restrained braces", Engineering. Structures, 77, pp. 143-160, 2014. https://doi.org/10.1016/j.engstruct.2014.07.034

[33] Judd, J. P., Marinovic, I., Eatherton, M. R., Hyder, C., Phillips, A. R., Tola Tola, A., Charney, F. A. "Cyclic tests of all-steel web-restrained buckling-restrained brace subassemblages", Journal of Constructional Steel Research, 125, pp. 164-172, 2016. https://doi.org/10.1016/j.jcsr.2016.06.007

[34] Chou, C.-C., Chen, S.-Y. "Subassemblage tests and finite element analyses of sandwiched buckling-restrained braces", Engineering Structures, 32(8), pp. 2108-2121, 2010. https://doi.org/10.1016/j.engstruct.2010.03.014

[35] López-Almansa, F., Castro-Medina, J. C., Oller, S. "A numerical model of the structural behavior of buckling-restrained braces, Engineering Structures", 41, pp. 108-117, 2012. https://doi.org/10.1016/j.engstruct.2012.03.045

[36] Lin, P.-C., Tsai, K.-C., Wu, A.-C., Chuang, M.-C., Li, C.-H., Wang, K.-J. "Seismic design and experiment of single and coupled corner gusset connections in a full-scale two-story buckling-restrained braced frame", Earthquake Engineering and Structural Dynamics, 44(13), pp. 2177-2198, 2015. https://doi.org/10.1002/eqe.2577

[37] Della Corte, G., D'Aniello, M., Landolfo, R. "Field Testing of AllSteel Buckling-Restrained Braces Applied to a Damaged Reinforced Concrete Building", Journal of Structural Engineering, 141(1), Article number: D4014004, 2015. https://doi.org/10.1061/(ASCE)ST.1943-541X.0001080

[38] Hu, J.-W., Choi, E. "Seismic design, nonlinear analysis, and performance evaluation of recentering buckling-restrained braced frames (BRBFs)", International Journal of Steel Structures, 14, pp. 683695, 2014.

https://doi.org/10.1007/s13296-014-1201-3

[39] Chou, C.-C., Liu, J.-H., Pham, D.-H. "Steel buckling-restrained braced frames with single and dual corner gusset connections: seismic tests and analyses", Earthquake Engineering and Structural Dynamics, 41(7), pp. 1137-1156, 2012. https://doi.org/10.1002/eqe.1176 
[40] Zhao, J., Lin, F., Wang, Z. "Seismic design of buckling-restrained brace welded end connection considering frame action effects: Theoretical, numerical and practical approaches", Engineering Structures, 132, pp. 761-777, 2017. https://doi.org/10.1016/j.engstruct.2016.11.069

[41] Avci-Karatas, C., Celik, O. C., Eruslu, S. O. "Modeling of Buckling Restrained Braces (BRBs) using Full-Scale Experimental Data", KSCE Journal of Civil Engineering, 23, pp. 4431-4444, 2019. https://doi.org/10.1007/s12205-019-2430-y

[42] Mahrenholtz, C., Lin, P.-C., Wu, A.-C., Tsai, K.-C., Hwang, S.-J., Lin, R.-Y., Bhayusukma, M. Y. "Retrofit of reinforced concrete frames with buckling-restrained braces", Earthquake Engineering and Structural Dynamics, 44(1), pp. 59-78, 2015. https://doi.org/10.1002/eqe.2458

[43] Zhang, J., Wu, B., Mei, Y., Shing, P. B. "Experimental and Analytical Studies on a Reinforced Concrete Frame Retrofitted with BucklingRestrained Brace and Steel Caging", Advances in Structural Engineering, 18(2), pp. 155-172, 2015. https://doi.org/10.1260/1369-4332.18.2.155

[44] Di Sarno, L., Manfredi, G. "Seismic retrofitting with buckling restrained braces: Application to an existing non-ductile RC framed building", Soil Dynamics and Earthquake Engineering, 30(11), pp. 1279-1297, 2010.

https://doi.org/10.1016/j.soildyn.2010.06.001

[45] Vaseghi Amiri, J., Naeej, M., Naeej, M. R. "Seismic Retrofitting of Steel Frames with Buckling Restrained Braces", Iranica Journal of Energy \& Environment, 4(3), pp. 178-185, 2013. https://doi.org/10.5829/idosi.ijee.2013.04.03.02

[46] American Institute of Steel Construction "Seismic Provisions for Structural Steel Buildings (ANSI/AISC 341-05 and ANSI/AISC 341s1-05) - 2005", American Institute of Steel Construction, Chicago, IL, USA, 2005.

[47] American Institute of Steel Construction "Seismic Provisions for Structural Steel Buildings (ANSI/AISC 341-10)", American Institute of Steel Construction, Chicago, IL, USA, 2010.

[48] American Institute of Steel Construction "Seismic Provisions for Structural Steel Buildings (ANSI/AISC 341-16)", American Institute of Steel Construction, Chicago, IL, USA, 2016.
[49] Kersting, R. A., Fahnestock, L. A., López, W. A. "Seismic Design of Steel Buckling-Restrained Braced Frames, A Guide for Practicing Engineers", National Earthquake Hazards Reduction Program (NEHRP), Gaithersburg, MD, USA, 2015. [online] Available at: https://www.nehrp.gov/pdf/nistgcr15-917-34.pdf

[50] Federal Emergency Management Agency "Prestandard and Commentary for the Seismic Rehabilitation of Buildings", FEMA, Washington, DC, USA, 2000. [online] Available at: https://www. nehrp.gov/pdf/fema356.pdf

[51] Zhao, J., Wu, B., Ou, J. "Effect of brace end rotation on the global buckling behavior of pin-connected buckling-restrained braces with end collars", Engineering Structures,815 40, pp. 240-253, 2012. https://doi.org/10.1016/j.engstruct.2012.02.030

[52] Tsai, K.-C., Hsiao, P.-C. "Pseudo-dynamic tests of a full-scale CFT/ BRB frame - part II: Seismic performance of buckling-restrained braces and connections", Earthquake Engineering and Structural Dynamics, 37(7), pp. 1099-1115, 2008. https://doi.org/10.1002/eqe. 803

[53] Hikino, T., Okazaki, T., Kajiwara, K., Nakashima, M. "Out-ofPlane Stability of Buckling-Restrained Braces Placed in Chevron Arrangement", Journal of Structural Engineering, ASCE, 139(11), pp. 1812-1822, 2013. https://doi.org/10.1061/(ASCE)ST.1943-541X.0000767

[54] Takeuchi, T., Matsui, R., Mihara, S. "Out-of-plane stability assessment of buckling-restrained braces including connections with chevron configuration", Earthquake Engineering and Structural Dynamics, 45(12), pp. 1895-1917, 2016. https://doi.org/10.1002/eqe.2724

[55] Zhao, B., Li, K., Liu, C., Fang, D., Wu, J. "Effects of Out-of-plane Brace-to-chord Angle on Multiplane CHS X-joints Behavior Under Brace Compression", Periodica Polytechnica Civil Engineering, 63(3), pp. 823-832, 2019. https://doi.org/10.3311/PPci.13738

[56] Hemati, S. A., Barkhordari Bafghi, M. A., Kheyroddin, A. "Experimental investigation of pod on the behavior of all-steel buckling restrained braces", Journal of Constructional Steel Research, 150, pp. 186-194, 2018. https://doi.org/10.1016/j.jcsr.2018.08.010 